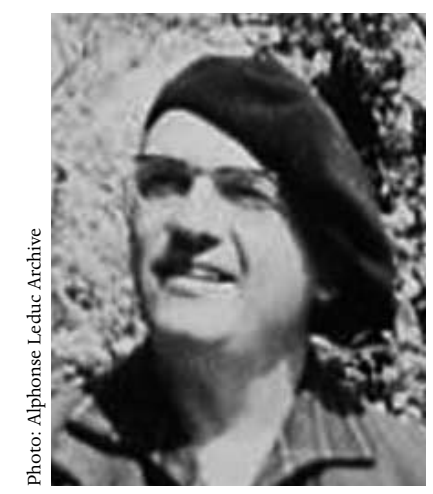

\title{
FORGOTTEN OFFERINGS: MESSIAEN'S FIRST ORCHESTRAL WORKS
}

\author{
Christopher Dingle
}

The prevailing image of Messiaen in the 1930s is of an organist-composer. One of the first things learnt about him is that he was organist at the church of the Trinite in Paris, having been appointed at the spectacularly young age of 22. As the earliest (though not the first) of Messiaen's works to have been published, the short organ piece Le Banquet céleste (1928) is, quite rightly, the focus of close examination for its precocious assurance. The 1930s were punctuated by the substantial organ cycles La Nativité du Seigneur (1935) and Les Corps glorieux (1939), so it is no surprise to find Felix Aprahamian's article for the fifth edition of Grove describing Messiaen as being a 'French organist and composer', and later observing that 'although it was as a composer of organ music that in pre-war years Messiaen's name first attracted attention, he had already composed a quantity of vocal music'. ${ }^{1}$ Fifty years later, Paul Griffiths similarly observed that 'Organ works featured prominently in his output of the next decade [1930s], but so did music about his family'. ${ }^{2}$ According to Harry Halbreich, 'one can say that before 1940, Messiaen was essentially an organist-composer, ${ }^{3}$ while, Malcolm Hayes concludes his chapter on the early orchestral music in The Messiaen Companion by stating that 'to judge from the idiom of his works written in the 1930s, he had once seemed destined to spend his creative life within the narrow confines of the organ loft' ${ }^{4}$

Despite these comments coming from some of the best-informed and perceptive advocates of Messiaen's music, it is a misperception to regard him as an organist-composer during the first few years of his career. There are six published works by Messiaen from the time before his appointment as organist of the grand orgue at the Trinité. ${ }^{5}$ Just two short pieces, Le Banquet céleste and the Diptyque, are for organ, and of these Le Banquet céleste turns out actually to be an adaptation of a pas-

\footnotetext{
${ }^{1}$ Felix Aprahamian, 'Messiaen, Olivier', in Grove Dictionary of Music and Musicians, 5th edn, ed. Eric Blom (London: MacMillan, 1954), Vol. 5, p.722.

2 Paul Griffiths, 'Messiaen, Olivier' in The Penguin Companion to Classical Music (London: Penguin, 2004), 504. The 'family' works are the Theme et variations (1932) for violin and piano, and the two song cycles Poèmes pour Mi and Chants de terre et de ciel.

${ }^{3}$ Harry Halbreich, Olivier Messiaen (Paris: Fayard, 1980), p.31.

${ }^{4}$ Malcolm Hayes, 'Instrumental and Choral Works to 1948' in The Messiaen Companion, ed. Peter Hill (London and Boston: Faber and Faber, 1995), p.198.

5 To these half dozen works might be added Messiaen's earliest known work, La Dame de Shalott, by virtue of the fact that he allowed it to be recorded and spoke of it in interview, even though it has never been published. Two short organ works from the extremities of the period under discussion in this article have recently been discovered and published, Prélude (c.1928) and Offrande au Saint Sacrement (c.1935). These works were never discussed by Messiaen nor were they listed, even in Technique de mon langage musical in which the composer included many student works, reputedly to make the list of works look more impressive (see Peter Hill, The Messiaen Companion, p.286). As a consequence, and while not disputing their undoubted interest, these works can be viewed as being non-canonical, occupying a similar position to the charming sight-reading piece uncovered by Nigel Simeone, Déchiffrage I, written for the Ecole Normale in 1934: see Nigel Simeone, 'Offrandes oubliées: Messiaen in the 1930s', Musical Times, 141 (Winter 2000), pp.33-41, and Peter Hill and Nigel Simeone, Messiaen (New Haven and London: Yale University Press, 2005), pp.50-51.
} 
sage from the unpublished orchestral work Le Banquet eucharistique. It might be thought that Messiaen's appointment to the Trinite would mark a flurry of organ works, but his first four years in post are not marked by an abundance of compositional riches for his instrument. He produced just one, relatively short, original organ piece, Apparition de l'église éternelle, the powerful exercise in crescendo and diminuendo redolent of Debussy's sunken cathedral. To this can be added the transcription of L'Ascension, of which only the third movement, 'Transports de joie' is a genuine organ piece.

In fact, for the early years of his professional career by far the greater part of Messiaen's creative energies were channelled into writing orchestral music. In 1930 he composed Les Offrandes oubliées, following this in 1931 with the symphonic poem Le Tombeau resplendissant. In 1932 he produced a further religious orchestral meditation Hymne au Saint-Sacrement and began work on yet another orchestral work, the four-movement cycle L'Ascension, which he completed the following year. This activity is all the more remarkable given that at this point in his career Messiaen was not composing in response to commissions. That he was prepared to invest the substantial amounts of time and effort required for composing a piece for large orchestra underlines the scope of his ambitions. He evidently felt that they were essential to being taken seriously as a composer, and they stand as an early marker of his intention to operate primarily on the big stage of orchestral repertoire.

While Les Offrandes oubliées and L'Ascension have received reasonable attention in the existing literature, Le Tombeau and the Hymne have struggled to gain attention and, when they have, it has been based upon erroneous information. ${ }^{6}$ Consequently, a significant portion of what follows is dedicated to these works, shedding light on their confused history and reinstating the original preface of the Hymne, from which it has been separated since 1942 . This story has never been fully unravelled before, and the appendix collates for the first time accurate information regarding all four works, including prefaces and significant recordings. The aim of the article is neither to provide a thorough analytical commentary on Messiaen's first three orchestral works, nor to suggest that Messiaen did anything other than make one of the greatest contributions to the organ literature. Rather, it explores why these works have been largely overlooked and, hence, why perceptions of Messiaen in the first five years of his career are so wide of the mark. ${ }^{7}$

Before considering the orchestral works themselves, it would be beneficial briefly to consider Messiaen's beginnings as an organist. Extraordinary as it may seem now, the instrument played no part in his

${ }^{6}$ Robert Sherlaw Johnson (Messiaen, 2nd edn, London: Dent, 1989) devotes only a brief paragraph to Hymne and makes no reference at all to Le Tombeau. There is no mention of either work in Michèle Reverdy's L'Euvre pour Orchestre d'Olivier Messiaen (Paris: Alphonse Leduc, 1988), while Pascal Arnault's more recent Messiaen: Les sons impalpables du rêve, (Paris: Millénaire III, 1997) mentions both in the worklist, but discusses neither, and even omits Le Tombeau from a list of early works. Hill and Simeone's seminal Messiaen devotes about a page to the two works, primarily noting the first performance details and an example of contemporary press reaction to each. Only Paul Griffiths, in Olivier Messiaen and the Music of Time (London: Faber and Faber, 1985), and Malcolm Hayes, ('Instrumental and Choral Works to $1948^{\prime}$ ), provide more substantial comment, with both writers devoting three (decidedly negative in the case of Hayes) paragraphs to Le Tombeau, and a single lengthy paragraph to the Hymne, and both base some of their suppositions on mistaken information. Crucially, Messiaen makes no mention of either work in his extended published interviews with Claude Samuel, Brigitte Massin or Almut Roßler.

${ }^{7}$ For further information on the reception history of these works, see Nigel Simeone, Olivier Messiaen: A Bibliographical Catalogue (Tutzing: Verlegt bei Hans Schneider, 1998); 'Offrande oubliées'; 'Offrandes oubliées 2: Messiaen, Boulanger and José Bruyr', Musical Times, 142 (Spring 2001), pp.17-22; and 'Group Identities: La Spirale and La Jeune France', Musical Times, 143 (Autumn 2002), pp.10-36; Hill and Simeone, Messiaen. 
original career plans. Interviewed for the parish magazine of the Trinite in 1991, Messiaen was asked: 'At the Trinité, your role is humble and hidden. Could this work as a liturgical organist be described as a vocation for you?' His response confirms that a career as an organist was not chief amongst his aspirations: 'It's not what I wanted at the start, but I have grown progressively accustomed to it' ${ }^{8}$ From his childhood, Messiaen's vocation, as he told various interviewers, was to be a composer. Although a committed Roman Catholic, it was not Messiaen's faith that led him to take up the organ. Rather his skill as an improviser prompted Jean Gallon, his harmony teacher, to recommend Messiaen to Marcel Dupré. Most extraordinary of all is that Messiaen was 18 years old before he first played an organ. Dupré later recalled that when Messiaen first came out to his house at Meudon

he sat stupefied in front of my organ keyboards. He had never seen an organ console before. After an hour of explanations and demonstrations, I gave him the Bach $\mathrm{C}$ minor Fantasia to learn. He came back a week later and played it to me by heart, perfectly; an astonishing feat!. ${ }^{9}$

He immediately began attending Duprés class at the Paris Conservatoire, firstly after Easter 1927 as an auditeur, before joining it officially following an exam on 17 December $1927 .{ }^{10}$ Within two years he gained his premier prix and barely four years after learning that first piece of Bach he gained his post at the Trinité. ${ }^{11}$ If Messiaen had so wished, his appointment at the Trinite could have acted as a springboard to a remunerative career as an organist-composer in the mould of Dupré. Instead, even when he did finally produce a substantial work for his own instrument, the celebrated cycle La Nativité du Seigneur, Messiaen did not give the first performance, remaining firmly in the audience as composer rather than organist. In a letter dated 11 May 1964 to Abbé Pézeril explaining his reluctance to write music specifically for the liturgy, Messiaen explicitly affirmed the pre-eminence of his orchestral works:

Unfortunately, I believe my music to be much too complex to be of use to you: it can only be played on the piano, on the organ, and above all by an orchestra [my emphasis]. ${ }^{12}$

The earliest of Messiaen's orchestral works about which we know anything beyond a name is Le Banquet eucharistique. Although it was never published, it warrants brief discussion as it was the first of Messiaen's orchestral works to be performed. It was composed at Fuligny during the summer of 1928, the same year that he began work on the piano Préludes:

When I was in Paul Dukas's class, I composed a work initially conceived for orchestra, and afterwards a second version for organ, at least of a passage taken from this work. [It had] a single beautiful moment, and this I kept and made into a little piece for organ, Le Banquet céleste. ${ }^{13}$

\footnotetext{
${ }^{8}$ Irène Meltzheim and Père Pascal Ide, 'Le musicien de joie: Entretien avec Olivier Messiaen 60 années à la Trinité', in Du coté de la Trinité (March 1991) pp.1-2.

${ }^{9}$ Marcel Dupré, Souvenirs, unpublished typescript, dated 'Noël 1956', p.97, cited in Hill and Simeone, Messiaen, p. 22.

${ }^{10}$ Marie-Louise Jaquet-Langlais, Ombre et Lumière - Jean Langlais 1907-1991, (Paris: Edition Combre, 1995), p.45.

${ }^{11}$ See Nigel Simeone, "'Chez Messiaen, tout est prière": Messiaen's appointment at the Trinité', Musical Times, 145 (Winter 2004), pp. 36-53 for a full account of Messiaen's appointment at the Trinité

${ }^{12}$ Hill and Simeone, Messiaen, pp.72-73.

${ }_{13}$ Brigitte Massin, Olivier Messiaen - une poétique du merveilleux, (Aix-en Provence: Alinéa, 1989), pp. $44 \& 46$
} 
To the surprise of his fellow students, Messiaen submitted Le Banquet eucharistique for the composition concours at the Conservatoire in 1929, but only received a deuxième prix, gaining his premier prix the following year, 'with some works which were far more anodyne'. ${ }^{14}$ It is remarkable, then, that the work was performed for the one and only time on 22 January 1930 by the orchestra of the Conservatoire under the Director, Henri Rabaud. ${ }^{15}$ At that time the orchestra rarely performed student works at all, so the inclusion of one that only achieved a deuxième prix was especially unusual. Messiaen's verdict later in life was damning:

I was only nineteen years old when I composed Le Banquet eucharistique. It was a very long work, neither very well scored, nor very well constructed. [...] I wrote in sonata form, but it was an entirely unsuccessful sonata form, with a development, but terribly scholarly, $[\ldots]$ it was truly a great naivety. ${ }^{16}$

He made a similar assessment to Almut Roßler:

It was a long symphonic poem, but then I found it bombastic, in other words, not good. I kept only the 2nd theme of it and rewrote it for organ. The 1st theme and the development - a proper one à la Beethoven - I discarded. ${ }^{17}$

If Messiaen found this first opportunity to hear an orchestra play his music to be a salutary experience, he was not downcast. At the first available opportunity, he turned his hand to orchestral composition once more with Les Offrandes oubliées, writing to Tournemire on 30 August 1930 to say that he had 'just finished the music for a symphonic poem'. ${ }^{18}$ This is the best-known of Messiaen's three early meditations for orchestra, and it marked several key staging posts in his career, being:

- the first of Messiaen's works to be performed by a professional orchestra and conductor.

- the first of Messiaen's orchestral works to be published.

- performed at the first concert of La Jeune France.

- the first of Messiaen's orchestral works to be performed in the USA. ${ }^{19}$

- the first of Messiaen's works to be recorded. ${ }^{20}$

The structure of Les Offrandes oubliées is mirrored by the composer's poetic preface to the score, with its three verses reflecting the titles Messiaen gives to the three sections; La Croix (The Cross), Le Péché (Sin), L'Eucharistie (The Eucharist):

Arms extended, sad unto death

on the tree of the Cross you shed your blood.

You love us, sweet Jesus: that we had forgotten.

Driven by folly or the serpent's tongue,

on a panting, frantic, ceaseless course,

we went down into sin as into a tomb.

Here is the spotless table, the fount of charity,

the banquet of the poor, here the Pity to be adored,

offering the bread of Life and of Love.

You love us, sweet Jesus: that we had forgotten. ${ }^{21}$

${ }^{14}$ Massin, Messiaen - une poétique du merveilleux, p.46.

${ }^{15}$ Hill and Simeone, Messiaen, p.25.

${ }^{16}$ Massin, Messiaen - une poétique du merveilleux, p.45

${ }^{17}$ Almut Rößler, Contributions to the Spiritual World of Olivier Messiaen, trans. Barbara Dagg and Nancy Poland (Duisberg: Gilles and Francke, 1986), p.140.

${ }^{18}$ Charles Tournemire (1870-1939) (L’Orgue: Cahiers et mémoires, no.41; Paris: Association des Amis de l'orgue, 1989), p.80, cited in Hill and Simeone, Messiaen, p.29.

19 Friday, 15 October 1936, Symphony Hall, Boston; Boston Symphony Orchestra, c. Serge Koussevitzky.

${ }^{20}$ Orchestre de l'Association de Concerts Gabriel Pierné, Roger Désormière (cond.), Paris, 1942, Association Française d'Action Artistique; AA6. This exceptionally rare recording was finally transferred to CD in 2006 for the EMI France set 'Les Rarissimes d'Olivier Messiaen', 094638527527.

21 See Appendix for the original French. 
While this may be characteristic of Catholic devotional writing of the time, this was not the kind of pronouncement typical of Parisian composers during, to borrow Roger Nichols's succinct epithet, the Harlequin years. ${ }^{22}$ Messiaen was rarely reluctant to discuss his music, and by far the majority of his major works have prefaces. However, those of the early works are unusual in that they consist only of an evocation of the subject-matter being depicted. In this respect, they follow the approach to programme music espoused by Liszt, while their earnestness foreshadows La Jeune France in its reaction against the aesthetic espoused by Cocteau. When L'Ascension received its first performance on 9 February 1935, Messiaen wrote an unsigned movement-by-movement commentary of the type that would soon become familiar, complete with musical examples in his own hand, for the 28 February edition of Le Monde musical. It contained specific information about the techniques being employed, such as, 'the first movement of L'Ascension is a majestic brass chorale. The solo trumpet sings and rises up on a mode of limited transposition, supported by spacious dominant chords'.23

In terms of style, several features of Les Offrandes oubliées stand out as setting the tone for years, or even decades, ahead. To start with, its tripartite, slow-fast-slow structure reflects Messiaen's penchant for clear-cut formal designs. Similar structures govern pieces such as 'Cloches d'angoisses et larmes d'adieu' from the Préludes and, as the name implies, the organ Diptyque. A similar approach can also be found in later works, notably the broad, two-part design of 'Les Stigmates' from the opera Saint François d'Assise. However, the music contained within each of the three segments of Les Offrandes oubliées is far more through-composed than would become the norm in the works of the composer's maturity.

The startling incursion of the middle 'Sin' panel into the rarefied world of the strings, breaking the contemplative mood with fortissimo trumpets underpinned by a heavy thump on the bass drum, is a key moment in Messiaen's development. This is the first of the extreme juxtapostions that would become his hallmark. It is not hard to find equivalent passages in later works, but the way that the bass drum in Éclairs sur l'au-delà... brutally dispels the rapt mood of the fifth movement, 'Demeurer dans l'amour', to herald the ensuing 'Les Sept Anges aux sept trompettes' is particularly close in spirit. In Les Offrandes oubliées the turbulent middle section rudely confounds the feigned resolution at the end of the doleful first section, providing evidence of the young composer's ability to manipulate audience expectations.

If this surprise is a marker for the future, the opening panel of Les Offrandes oubliées is remarkable within Messiaen's output as a whole for being built upon a clear foundation of minor harmonies, in this case $\mathrm{E}$ minor. Many of Messiaen's harmonies have clear associations with tonal harmony, a fact readily acknowledged by the composer himself. ${ }^{24}$ However, these are almost without exception to major rather than minor triads. Messiaen's inclination towards the major permeates his output to such an extent that the occurrence of a prominent minor triad in the left hand in 'Je dors, mais mon cœur veille', the penultimate piece

\footnotetext{
22 Roger Nichols, The Harlequin Years: Music in Paris 1917-1929, (London: Thames \& Hudson). For an excellent examination of Messiaen's attitude to Cocteau, see Stephen Broad, 'Messiaen and Cocteau' in Olivier Messiaen: Music, Art and Literature, ed. Christopher Dingle and Nigel Simeone (Aldershot: Ashgate, 2007).

23 The full commentary is reproduced in Hill and Simeone, Messiaen, p.53.

${ }^{24}$ See, for instance, Olivier Messiaen, Traité de rythme, de couleur, et d'ornithologie - Tome VII, (Paris: Alphonse Leduc), pp.137-38.
} 
of the Vingt Regards, is a startling sonority. The only extended passage with a minor hue in Messiaen's later music is 'Le Courlis cendre', the doleful final piece of Catalogue d'oiseaux (1956-58).

The final section of Les Offrandes oubliées is the first of Messiaen's orchestral louanges. Even at this stage, his precision with the scoring is striking. First violins carry the melody, accompanied by just nine solo strings (four second violins and five violas), the entire ensemble being muted. While the precise number of accompanying strings varied over the years, ${ }^{25}$ he only made one substantive change in later works to the principle of this scoring by having the accompanying solo strings play without mutes. The first occurrence of this refinement came just three years after Les Offrandes oubliées when Messiaen orchestrated the final movement of L'Ascension, 'Prière du Christ montant vers son Père'. ${ }^{26}$

It is the music of the slow outer sections of Les Offrandes oubliées, with their modally inflected melodic and harmonic material and a rhythmic fluidity derived from plainsong, that undoubtedly sound most characteristic of Messiaen. It is possible in the truculent middle section to detect the fingerprints of Ravel, Stravinsky, Bartók and Messiaen's composition teacher, Dukas. Messiaen's Conservatoire training is also to the fore in the way that the same material forms the basis of the disparate music of all three sections, this distinctly Franckian cyclic theme justifying the subtitle of 'Méditation symphonique'. It is certainly not that the music lacks individuality. Rather that Messiaen's orchestral music had yet to make a definitive break with the sound-world of the preceding generation. For instance, the strings are still the foundation of the orchestration. The remarkable feat in these early orchestral works is not that it is possible to note influences, but that so much is unmistakeably by Messiaen. Moreover, they were written in an age dominated by the insipid Saint Sulpice style, with few, if any, precedents for lively religious music that was not derived from the standard liturgical forms.

During the summer of 1931, a year after he composed Les Offrandes oubliées, Messiaen wrote one of his most extraordinary works, Le Tombeau resplendissant. Malcolm Hayes is admittedly dismissive of it, suggesting that Messiaen 'offers very little that the earlier work [Les Offrandes oubliées] does not. A harsh commentator could even make out a case that Messiaen here virtually wrote the same piece twice' ${ }^{27}$ On the structural level there is some justification to this charge. There is a clear parallel in sensibility between the slow-fast-slow form of Les Offrandes oubliées and the fast-slow-fast-slow structure of Le Tombeau, especially when strings dominate the final slow sections and trumpet and bass drum feature prominently in the fast music. Nonetheless, the querulous first and third sections of Le Tombeau are markedly different in approach not just from the 'Sin' episode of Les Offrandes oubliées, but from anything else in Messiaen's œuvre. This music has a rage that might be thought anathema to the composer. Within the overall sense of headlong fury, there is a deliberate disjointedness allied to an expansive orchestration, as if attempting to reconcile what had been learnt from The Rite of Spring with the orchestral approach of Daphnis et Chloë. It is notable, also, that, for better or worse, Messiaen avoids giving prominence to a single unifying theme as he did in Les Offrandes oubliées.

\footnotetext{
25 'Demeurer dans l'amour', the fifth movement of Éclairs, uses six each of second violins, violas and cellos.

${ }^{26}$ L'Ascension is the first work in which Messiaen specifies what would become his standard complement of 16.16 .14 .12 .10 , though it is worth noting that the score was not published until 1948.

${ }^{27}$ Hayes, 'Instrumental and Choral Works to 1948 ', p. 170 .
} 
Messiaen finally slams on the brakes in the first and third sections of Le Tombeau with a piece of musical punctuation that comes almost directly from L'Apprenti sorcier (Example 1).

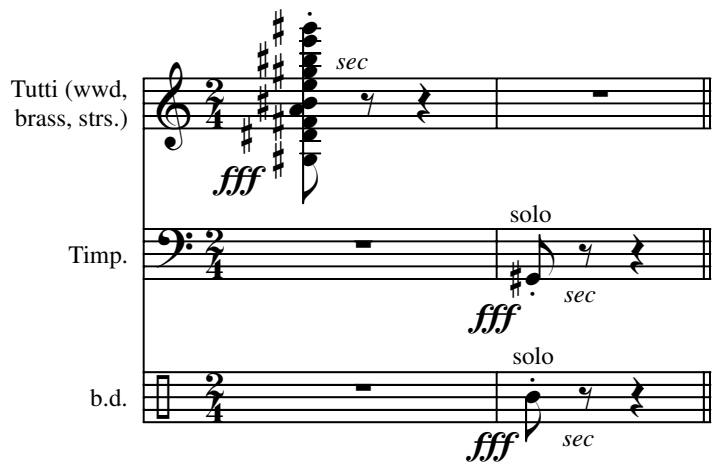

Echoes of this unassuming borrowing from his teacher - an emphatic juxtaposition of high and low with bass drum adding punch to the latter - can be found throughout Messiaen's output, notably at the end of 'Turangalîla 2', in the 'decision' theme from Saint François, and the opening and closing of 'Le Chemin de l'invisible' from Éclairs. More assuaging music follows on both occasions, with the lyrical second section of Le Tombeau giving a foretaste of Messiaen's orchestration of Poèmes pour Mi. The final string section is directly analogous to the end of Les Offrandes oubliées. However, aside from harmonic and melodic differences, there is a significant variant in the orchestration. Uniquely among such passages, Messiaen hands the melody to the entirety of the violas and cellos, with six solo first violins and four solo second violins accompanying. As with Les Offrandes oubliées, all of the strings are muted, but here the melody starts below the accompaniment and gradually moves through the texture to end up on top. The result is not as luminescent as the earlier work or the closing pages of L'Ascension, but such comparisons are misleading, for this piece is more about personal faith than a depiction of transcendent events.

Like Les Offrandes oubliées, Messiaen gave Le Tombeau a poetic preface. However, even the most loyal of his friends must have been left bemused by the desperately vivid imagery with which he so publicly bares his soul: ${ }^{28}$

My youth is dead: I am its executioner. Anger bounding, anger overflowing! anger like a spurt of blood, anger like a hammer blow! A circle at the throat, hands full of rage, a face of cold hate! Despair and weeping!

My youth was lived in a music of flowers. I had in view an enchanted stairway. On it shone the plumage of the bluebird of illusions. The melody of the atmosphere rose up, joyously sad.

My youth is dead: I am its executioner. Where, fury, are you leading me? Why trees do you gleam through the night? Advance, retreat, hold out your arms! A sea swells at my ears! and it cracks, spins, dances, shouts, yells: the void enters into me!

What is this resplendent tomb? It is the tomb of my youth, it is my heart. Lit by the flame forever surging, lit by the blinding clarity of an inner voice: 'Come unto me, all you who labour and are heavy laden, and I will give you rest. Blessed are the meek, for they shall inherit the earth. Blessed are they that mourn, for they shall be comforted. Blessed are the pure in heart, for they shall see God. ${ }^{29}$

\footnotetext{
28 A facsimile of Messiaen's autograph preface on an early hire score is reproduced in Simeone, Messiaen: A Bibliographic Catalogue, p.25.

${ }^{29}$ See Appendix for original French.
} 
Speaking to José Bruyr only weeks after completing the work, Messiaen explained that 'I wanted to write a kind of Beatitude for those who discover in their faith something more than illusions of a distant youth'. ${ }^{30}$ Even taking into account the assuaging quotation from the Sermon on the Mount at the end of this outburst, this hardly explains the extreme picture of anger and despair portrayed by the first and third parts of the text. It is not the graphically violent language that shocks those accustomed to Messiaen's other prefaces, for there is plenty of evidence throughout his life of his penchant as a child for, 'everything that frightens' ${ }^{31}$ Rather, it is the element of a frank autobiographical confession that disconcerts.

Quite what prompted these painful outpourings is unclear. In his book of autobiographical musings, Images, Messiaen's father, Pierre, observed that, 'my children do not like to discuss the Great War and the following years' ${ }^{32}$ Messiaen remained discreetly silent not only about this period, but about the various problems and tragedies with which his personal life was blighted, making the very public agonies of $L e$ Tombeau even harder to fathom. It is tempting to speculate that he is attempting to lay to rest some aspects of the grief that he felt at the death of his mother in 1927. That Cécile Sauvage is still the great influence on his life is not in doubt, for, as he explains to Bruyr it often seems to me now that it is my mother, after her death, who guides my hand or my spirit'. ${ }^{33}$ Nevertheless, his comments to Bruyr about 'illusions of a distant youth' suggest that in his early twenties Messiaen was also clarifying the distinction between the fairytales or Shakespearean fantasies with which he was besotted as a child, and the 'marvellous' aspects of his faith in which 'it was no longer a matter of theatrical fiction but of something true'. ${ }^{34}$

While the 22-year-old Messiaen may have had few qualms about parading his growing pains so publicly, it would appear that doubts did not take too long to emerge. Le Tombeau was given its first performance by the Orchestre Symphonique de Paris under Pierre Monteux at the Salle Pleyel in Paris on Sunday 12 February 1933. Following this, Messiaen did not actually withdraw the work, but he made little effort to promote it or to have the score published for sale: Durand held the material but a printed score did not appear until 1997. No commercial recording was made until September 1994. It was included in the work list at the end of Technique de mon langage musical (1944), but Halbreich related that 'Messiaen does not want it to be performed, nor for it to be discussed'. ${ }^{35}$

As with the best intrigues, the story of Le Tombeau has also been muddied by a marvellous red herring. An entirely different, more benign preface, which was 'inscribed at the head of the score' and reprinted at the composer's request, was attributed to the work by Henri Martelli in Revue musicale: ${ }^{36}$

I sing of the gift of the divine essence,

The flesh of Jesus Christ

His flesh and his blood,

I sing of the banquet of struggle and strength

${ }^{30}$ Interview (October 1931) in José Bruyr: L'écran des musiciens, seconde série (Paris: José Corti, 1933), pp.124-31, cited in Simeone, 'Offrandes oubliées 2', pp.21-22.

${ }^{31}$ Cécile Sauvage, Oeuvres completes (Paris: La Table Ronde, 2002), p.244.

${ }_{32}$ Pierre Messiaen, Images, (Paris: Desclée de Brouwer, 1944), p.153.

${ }^{33}$ Bruyr, 'Interview', cited in Simeone, 'Offrandes oubliées 2', p.20.

${ }^{34}$ Samuel, Music and Color, p.26.

${ }^{35}$ Halbreich, Messiaen, p. 348

${ }^{36}$ Henri Martelli, 'Olivier Messiaen: Le Tombeau resplendissant', Revue musicale 138 (July-Aug 1933), 128-29. 
(Bond of unity in love)

I sing of who is in us (and we are in him)

The living bread descending from heaven,

The living bread who gives life,

Eternal life! $!^{37}$

This unequivocal statement of Catholic Eucharistic theology is much closer to what we expect from Messiaen than any heart-on-sleeve anguishing about executing his youth. This text has been taken by Griffiths, among others, to apply to Le Tombeau. As for the "youth is dead' preface, Griffiths suggests that it might have been 'suppressed at the time of the first performance'. ${ }^{38}$ Unfortunately, Griffiths and others made the wrong assumption..$^{39}$ Martelli's claim for the text is not only contradicted by the autograph score, but also by other reviews of the first performance, such as that by Tristan Klingsor, who noted in $L e$ Monde Musical on 28 February 1933 that the work, is the "tombeau" of the composer's youth'. ${ }^{40}$ The reviews in Le Courrier musical and Le Ménestrel also mention nothing of the Eucharist, but do mention that the work is the 'tombeau' of the composer's youth. ${ }^{41}$ The text reproduced by Martelli is not an abashed Messiaen's alternative, more acceptable preface to Le Tombeau.

So where did Martelli get his text? The simple, but thus far overlooked, answer is that he made a mistake. His text is the preface for the Hymne; a fact confirmed by a document that has only recently come to light - the programme for the concert at which the work received its first performance on 23 March 1933, just 40 days after Le Tombeau. ${ }^{42}$ In the extremely unusual circumstance of a very young composer having two first performances within six weeks of each other, it seems that Martelli simply got confused about which work was which and wrongly assigned his text.

The programme for the first performance of the Hymne contains an uncredited note on the work which, if not by Messiaen himself, is clearly a more or less verbatim repetition of information provided by the composer. After a couple of short background paragraphs, the form of the work is related directly to the theological symbolism in a manner typical of the young Messiaen:

This work is written in a sonata form comprising two themes, with two developments. The first, laudatory theme, sings the glory of the Lord; the second expresses the union of love between Jesus and the communicant. The central development is charged with evoking the mysterious battle of man against sin, helped by the grace obtained through communion.

The two themes are then subject to a re-exposition. The final development exults in the Host, the pledge of unending joy in heaven.

\footnotetext{
${ }^{37}$ See Appendix for original French.

${ }^{38}$ Paul Griffiths, Olivier Messiaen and the Music of Time (London and Boston: Faber and Faber, 1985), pp.48-49.

39 Although expressing scepticism and noting the 'Youth is dead' preface on the score, even Nigel Simeone reproduces the text in his Catalogue under the entry for Le Tombeau resplendissant in his Messiaen: A Bibliographic Catalogue, pp.23-24.

${ }^{40}$ Hill and Simeone, Messiaen, p.45

${ }^{41}$ See Simeone, Messiaen: A Bibliographic Catalogue, pp.213-14.

${ }^{42}$ The programme for the first performance was one of the vast number of documents encountered by Nigel Simeone and Peter Hill in Messiaen's personal archive. With such a wealth of material, it is no surprise that this programme was not initially examined especially closely. In papers on aspects of this article given at Sheffield in February 2003, at UCE Birmingham Conservatoire in December 2004 and at the RMA annual conference in Manchester in November 2005, I stated my belief, based upon the existing evidence, that Martelli's text applied to the Hymne rather than Le Tombeau resplendissant. When discussing this article with Nigel Simeone in January 2006, he thought initially that he did not have a copy of the programme. While looking for other documents in relation to this article, he discovered that he did have a copy of the programme, and the hypothesis was confirmed.
} 
The note then gives the text reproduced by Martelli, confirming that it was at the head of Messiaen's score. Even before this crucial piece of evidence, a vital, but repeatedly overlooked, clue was provided by the verbatim quotation of the final two lines of Martelli's text at the conclusion of a review of the first performance of Hymne by 'F.D.' in Le Courrier musical. ${ }^{43}$

Martelli's error should, and would, have been spotted years ago, but an element of farce creeps in at this point. In the autumn of 1942 all of the material for the Hymne was sent to Lyon. On 16 November, Messiaen noted in his diary, 'Telephone Durand about the manuscript score and parts of Hymne which are being sent to Lyon. Have they arrived?'44 Messiaen made a further entry on 19 January 1943: 'write to Jean Witkowski in Lyon about the material for the Hymne au Saint-Sacrement. How was it sent? Perhaps it is still with Béal [the leading Lyon music dealer]. ${ }^{45}$ The work never arrived in Lyon. Remarkable as it may seem now, in an age of photocopiers and scanners, no copy of the music was kept. It has thus been impossible to check what, if anything, was inscribed at the head of the original score of the Hymne.

In 1946 Leopold Stokowski enquired about performing the work with the Philharmonic Society of New York for a concert on 13 March 1947. Messiaen, no doubt at pains not to disappoint the conductor made a household name by Disney's Fantasia, reconstructed the score. To add to the confusion surrounding the piece, it was erroneously billed as a first performance. The programme note, by R.C.B. [Robert C. Bagar] but clearly based upon information supplied by the composer, gives the clear impression that this is a new work: 'The idea for this composition dates back to 1932, although, excepting the thematic sketches, not much was done about it at the time. Not until 1945 did the composer return to "Hymne," when he developed his original material to the present form." This conveniently overlooks the performance under Straram in 1932, and at least one other performance, under Roger Désormière, at the inaugural concert of La Jeune France on 3 June $1936 .{ }^{46}$ It is possible that the composer saw little harm in some mild dissembling to resurrect a work that had effectively ceased to exist. It is also plausible that Stokowski embroidered the known facts in order to claim another première - not that this impressed, for Miles Kastendieck records in the New York Journal American that it turned out to be something of a dud with the audience' ${ }^{47}$ This is countered to a degree in The Herald Tribune by Virgil Thomson, who had already encountered Messiaen's music in the febrile atmosphere of Paris at the end of the war:

It is really not very important whether Messiaen's pieces 'come off' or not. To date none of them does. But they are powerful and original music all the same. It is our obligation as listeners, therefore, to get inside them, since they do not easily penetrate our customary concert psychology. If we do not, we are missing a valid musical experience. ${ }^{48}$

One piece of evidence supporting the idea that it was Messiaen who had to visit his confessor is that he gave the reconstructed version of the

\footnotetext{
43 Le Ménestrel, xxxv (1933), no.8, 15 April 1933, p.196, cited in Simeone, Messiaen: A Bibliographic Catalogue, pp.215-16. Other reviews also mirror Martelli's text.

44 Hill and Simeone, Messiaen, p.120.

${ }^{45}$ Hill and Simeone, Messiaen, p. 120.

${ }^{46}$ Les Offrandes oubliées was also performed at this concert.

47 Miles Kastendieck, 'French Music Featured' New York Journal American (14 March 1947).

48 Virgil Thomson, 'Excellence by Pairs', The Herald Tribune, (14 March 1947).
} 
work the shorter title of Hymne. The broad two-part form of the work, collating disparate musical elements, reflects the binary nature of the Eucharist, but the new score contains no preface..$^{49}$ Moreover, the programme note for the first performance of the reconstructed work gives no indication of the precise subject matter of this Hymne. This note directly quotes 'the composer's analysis of the music'; a text that replaces theological symbolism with a musical commentary drawing upon Messiaen's idiosyncratic terminology:

The work is based on two themes, with a middle and final development. The first theme ends with a burst of winds on the chords of the dominant [sic] appoggiatura. ${ }^{50}$ The second theme, more dreamy and very singing, built on the 'modes à transposition limitées,' utilizes only violins and violas soli. The middle development is 'polymodal,' alternating with and opposing the more belligerent first theme and the more passionate second theme. The final development resumes the martial character and the 'polymodality' of the first development, and concludes on a joyous fanfare of brass, surrounded by a shimmering of all the instruments of the orchestra in the tonality of B major.

Apart from the 'burst of winds', which might be taken as a reference to the Holy Spirit, there is nothing in this to suggest Messiaen's original programme, or even title for the work. It is hardly surprising, then, that Harold C. Schonberg commented in the New York Sun that the Hymne 'has few characteristics that are ecclesiastical, despite the title'. ${ }^{51}$ Aside from the lack of religiosity, the 1947 commentary also omits any mention of colour, the prevalent feature of the programme note on the Hymne generally known, and which the composer began using, with minor variants, from the 1960 s. By this point, he was happy to give the work its true dating:

As in my Préludes for piano (written in 1929), this work (which dates from 1932) is characterized above all by its colour effects. A first theme, like a gust of wind, uses the colours of the chords. The second theme juxtaposes the colours of three 'modes of limited transposition'. In the development (of the first theme), the lyric explosions contrast the staccato of the woodwinds with the fullness of the horns, under the melodic line of the violins. There, the music combines gold and brown to orange striped with red, orange and milk white to green and gold. A full crescendo takes off on the blue-violets and greens, and rises up to the red and gold of the final fanfare of the trumpets, which magnifies the lyric element. $^{52}$

The brief paragraph on the work by Robert Sherlaw Johnson ${ }^{53}$ essentially paraphrases this programme note, discussing the Hymne in Messiaen's retrospectively applied sound-colour terminology.

In the diary entries from November 1942 and January 1943 quoted above, Messiaen still referred to the work as Hymne au Saint-Sacrement. It is possible only to speculate about what had changed by 1946 in order to necessitate shortening the title to Hymne. One factor may have been that, having lost the original version, Messiaen did not want Durand claiming rights for the reconstruction. However, in addition to possibly covering his tracks regarding the provenance of the Hymne, it also seems pertinent that when Messiaen made his reconstruction, he was still being subjected to the vicious critical attacks that began with the first performances of the Vingt Regards and the Trois Petites liturgies and rapidly came to be known as 'le cas Messiaen'. From 1945 until the composition of

\footnotetext{
49 Publication of the reconstruction was entrusted not to Durand but, uniquely in Messiaen's output, to an American firm, Broude Brothers.

${ }^{50}$ This mistranslation is presumably referring to Messiaen's 'accord sur le dominant appogiaturé, the most famous examples of which occur in the piano part during the opening bars of 'Liturgie de cristal' from Quatuor pour la fin du Temp.

${ }^{51}$ Harold C. Schonberg, 'Casadesus Plays French Music', New York Sun, (18 March 1947)

52 Sleeve notes to Erato LP STU 70763. See Appendix for full discographic details.

53 Johnson, Messiaen, p.29
} 
Couleurs de la cité céleste in 1963, Messiaen composed no explicitly religious works for the concert hall. Having been given such a torrid time over his most recent works, it is plausible that Messiaen decided that he did not wish to give ammunition to his critics in the form of a youthful work tackling one of the central mysteries of his faith. Regardless of the reason, by the time that the work was recorded by Erato in 1971 under Messiaen's supervision, the full title was back in use..$^{54}$

The question remains regarding the accuracy of the reconstruction. It is, of course, impossible to be certain. Despite the differences, the three commentaries by Messiaen are clearly referring to the same (or at least a very similar) piece of music. Nor was this the first time that Messiaen's memory was put to the test. The fifth and eighth movements of the Quatuor pour la fin du Temps are essentially verbatim transcriptions of sections from Fête de belles eaux and the Diptyque respectively, made when Messiaen was a prisoner, and thus, unable to access the original works. There are also numerous testaments to Messiaen's extraordinary facility for remembering music, not least his ability when teaching to recall extensive and varied passages of music. Crucially, if Messiaen's working practices for his early works were the same as for his late works, it is possible, also, that he had sketches, or even a short score, so that the task was more a case of re-orchestrating rather than recomposing.

A short six-bar fragment equivalent to figure 3 in the published score appears as example 367 of Technique de mon langage musical. As Nigel Simeone has observed, ${ }^{55}$ there are no divergences between the two in terms of the notes themselves: pitch and rhythm are identical. However, there are some minor differences in terms of dynamics and tempo marking. Messiaen had completed writing Technique by October 1942, shortly before the loss of the Hymne. However, we do not know whether the many musical examples are taken directly from the scores of the pieces in question, or, like his illustrations at the piano when teaching, were reproduced from his capacious memory as he worked upon the text.

Both Hayes and Griffiths suggest that, since work on reconstructing Hymne occurred while Messiaen was also getting to grips with Turangalîla, the symphony will have left its mark on the rewritten version. Maybe so, but it is too simplistic to suggest that the traffic was one-way, for it is just as plausible that the work on reconstructing Hymne stimulated ideas for Turangalîla. What can be said with confidence is that the reconstruction does not sound like a work from the same era as Harawi and Turangalîla-symphonie. There is one small clue in the orchestration that Messiaen was trying to remain faithful to the original: the inclusion of timpani. Despite extensive use of percussion in his orchestral works, from the 1940s onwards, timpani are notable by their absence from his music. Indeed, it is arguable that it is the humble timpani that place the livelier music in these early works so firmly in the soundworlds of his immediate predecessors. ${ }^{56}$ If Messiaen wished to update the work, it would have been easy for him to use a more progressive orchestral texture.

One passage of Hymne in which there is a clear link with Turangalîla is in the build-up to the first occurrence of the exuberant tune that forms

${ }^{54}$ When Stokowski conducted the work in Frankfurt on 31 May 1955, the title was still 'Hymne', and the performance was billed as the 'European première', without specifying that it was of the reconstructed version. The material available for hire from Broude Brothers from 1947 used a facsimile of the composer's autograph score. The engraved score, produced in 1974, was based upon that facsimile and still gives the title simply as Hymne.

55 Simeone, Messiaen: A Bibliographic Catalogue, p.30.

${ }^{56}$ It is also worth noting, in passing, that, despite its celestial connotations, Messiaen never included the harp in his orchestra. Boulez, by contrast, makes extensive use both of harp and timpani. Rather less surprising, given his dislike of jazz, is the complete absence of the saxophone from Messiaen's music. 
the peroration for both panels of the work (Example 2). The stepwise contrary motion can be found repeatedly in the exaggerated climaxes leading into (or, occasionally, feigning to lead into) the symphony's love theme. ${ }^{57}$ However, since Hymne is concerned with the 'Bond of unity in love' and Turangalîla is concerned with ecstatic love, it is not especially surprising that there should be some similarities in the gestures of this emotional outburst. Other features of the Hymne also find resonances in Turangalîla, notably the brass-dominated descending tritones that launch the faster sections, but these equally foreshadow 'Le Chemin de l'Invisible' from Éclairs.

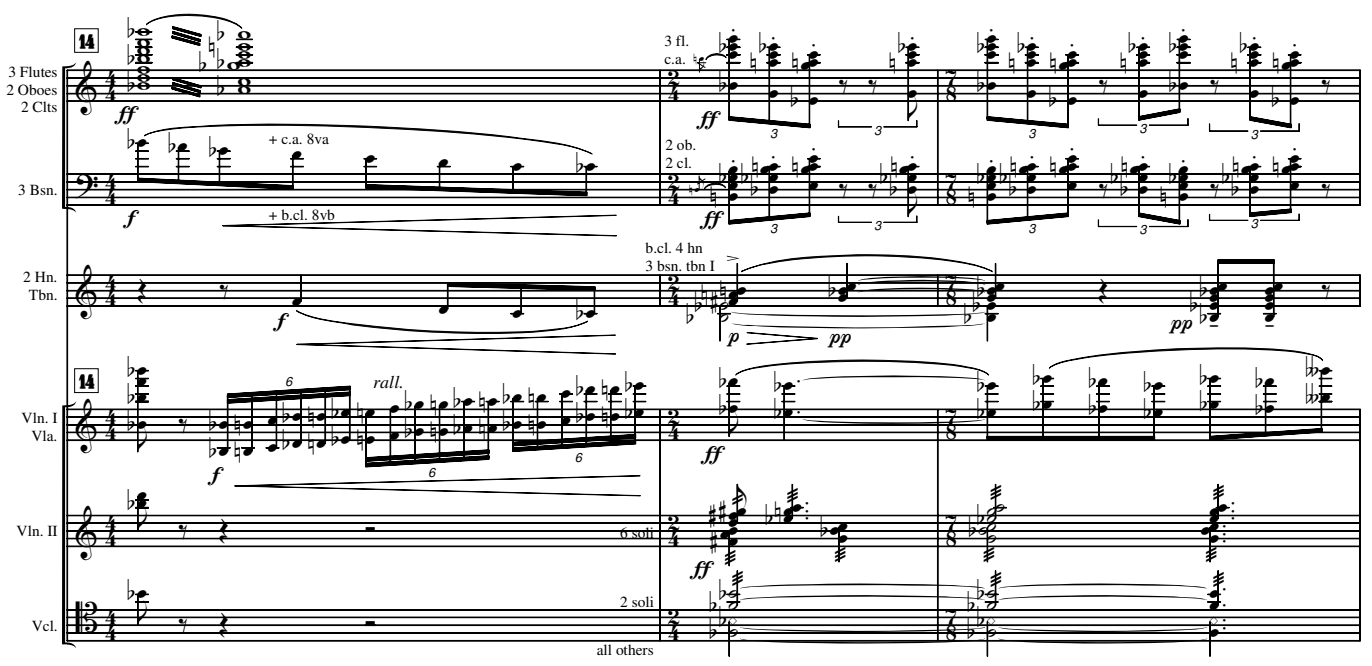

One aspect of the Hymne that, unless Messiaen composed an entirely new work, cannot be attributed to the influence of Turangalîla, is that it marks the first time that Messiaen writes fast music for orchestra that is positive in outlook. Moreover, whereas the faster pieces among the eight piano Préludes struggle to maintain their momentum, there is a clear impetus throughout the Hymne. In structural terms, too, the Hymne represents an advance. The bi-partite form, with its two near-identical panels each consisting of several distinct types of music, is a fore-runner of the mosaic structures of Messiaen's maturity, such as 'Perfecte conscius illius perfectae generationis', the ninth movement of $\mathrm{La}$ Transfiguration, or the second movement of Éclairs, 'La Constellation du Sagittaire'. For this reason alone the Hymne deserves greater attention, quite apart from being an impressive work in its own right.

Of the four works written before 1935, L'Ascension has stolen the limelight. Begun when the ink was barely dry on Hymne, underlining the extent to which Messiaen regarded himself as being primarily a composer of orchestral works, this cycle of four meditations is marked by its forward-looking, bold structure and gestures. With a majestic opening chorale for winds, and an incandescent slow final movement for strings, which are both dedicated to aspects of the figure of Christ, L'Ascension is an early example of the musical structure supporting theological symbolism. Christ is the Alpha and the Omega, the beginning and the end, encompassing everything in the orchestra from winds to

57 See 'Chant d'amour 1' figure $13^{-1}$, 'Chant d'amour 2', figures $5^{-1}$ and $14^{-2}$, and 'Developpement de l'amour' figures $15^{-4}, 26$ and 41 . 
strings. As important as the symbolism itself is the audacity with which it is conveyed. Leaving entire sections of the orchestra silent for movements at a time is a considerable risk, but it is clear from the outer movements of L'Ascension that Messiaen already has a steady nerve and the force of personality to make it work.

However, in addition to the undoubted advances, there are also aspects of L'Ascension that are relatively weak. Messiaen effectively acknowledged this a decade later when he rated the compositions in his catalogue of works in his first treatise, Technique of my Musical Language. ${ }^{58}$ Like a Michelin rating, Messiaen awarded one star to works that he regarded as 'characteristic' of his musical language, and two stars to 'very characteristic' works. It is no surprise that the double star rating tends to be given to more recent works, such as Les Corps glorieux. Had he revisited the list a few years later, it is possible that a three-star category would have been added for Harawi and Turangalîla. Most of the more substantial early works, including both Les Offrandes oubliées and the Hymne, are awarded one star, marking them as 'characteristic'. It is no shock that Le Tombeau receives no stars. What is astonishing is that L'Ascension is also bereft of stars. Messiaen places his most substantial orchestral work to date on a par with the distinctly uncharacteristic Fantaisie burlesque. ${ }^{59}$ Moreover, he regards Les Offrandes oubliées and the Hymne as being more representative of his music.

It is the third movement of L'Ascension, 'Alléluia sur la trompette, Alléluia sur la cymbale', that shows least signs of progress beyond anything Messiaen had composed up to this point. The end of the movement is an unconvincing attempt to apply principles learnt from studying Stravinsky, but it lacks impetus. It is ironic, then, that when he came to transcribe L'Ascension for organ, a task that he found uncommonly arduous, he struggled interminably with this movement, only to end up replacing it with what rapidly became one of his most celebrated toccatas, 'Transports de joie'. Organists may not like the idea, but the transcription of L'Ascension was just that; a transcription. For Messiaen, the organ version was not a work in its own right; L'Ascension was an orchestral work, and the organ transcription simply enabled a wider audience to acquaint themselves with it. He had made a piano version of Les Offrandes oubliées - a common practice for orchestral works until recordings became more prevalent - and the organ version of L'Ascension can be regarded as fulfilling the same function for that work. Messiaen later stated bluntly that, 'my fourth organ work doesn't deserve this title because it's actually a transcription of a work for orchestra: L'Ascension'. ${ }^{60}$

The difficulty that he encountered when transcribing L'Ascension seems to have clarified for Messiaen that he could not follow Milhaud's example and increase his productivity (and fees) by producing several versions of each work for different genres. While they might explore similar subjects, Messiaen never again allowed his orchestral and his organ music to overlap in terms of substance. It was unfortunate, then, that the list of works in Technique de mon langage musical erroneously stated that the organ transcription was composed in 1933 and the orchestral version in 1934 - in other words, that the organ version came first. The two-fold result of this misdating was that the organ version

\footnotetext{
58 Olivier Messiaen, Technique de mon langage musical (Paris: Alphonse Leduc, 1944) 1er vol., pp.64-67; 1999 single volume edition, pp.107-109.

59 When a new edition of Technique appeared in 1999, several years after Messiaen's death, both versions of L'Ascension had magically acquired two stars - is it a mere coincidence that Alphonse Leduc publishes both the Technique and L'Ascension?

${ }^{60}$ Samuel, Music and Color, p.118.
} 
was regarded as a fully-fledged work and, as a result, added to the misperceptions of Messiaen as being primarily a composer of organ works during the 1930s.

The question remains as to why, after four years where orchestral works were the focus of his compositional activities, Messiaen then turned to other genres. Rather than remaining the mainstay of his output, from 1935 until 1959 Messiaen made only intermittent forays onto the orchestral stage. Needless to say, creative ambitions change and external circumstances impinge in unpredictable ways. Messiaen told Samuel that:

I held myself back in my early organ works, knowing that they would be played in church. When I first started as organist at the Trinité, I was the object of hatred and protest from the parishioners, especially the old ladies who heard the devil in the organ pipes. ${ }^{61}$

As Messiaen became better acquainted with his instrument, and his position at the Trinité became more secure, his ambitions for the organ increased. Furthermore, by the late 1930s, Messiaen was certainly more aware of the difficulties, notably financial, of getting orchestral works performed. The concerts of La Jeune France were only possible thanks to Yves Baudrier's enthusiastic, though personally ruinous, backing, with support for the arts in France declining significantly in the latter years of the 1930 s, only truly to return in the 1960 s. $^{62}$ Simultaneously, the more intimate genre of the song cycle became Messiaen's chosen forum to express his love for his wife, Claire Delbos. Later came the impact of the Second World War, the influence of Messiaen's students and, crucially, the prolonged domestic disruption caused by the long illness of Delbos. Finally, this brief litany would be incomplete without noting that, from 1943, the extraordinary pianism of Yvonne Loriod provided the catalyst for the piano to move centre stage in the composer's music.

The composition of Chronochromie (1959-60) marks the point where the orchestra, in as many configurations as there are works, decisively became the principal focus of Messiaen's creativity for the remainder of his output. It is a period where his music is demonstrably 'above all for orchestra', featuring in 12 of the 17 works composed. Even when voices are involved, in La Transfiguration and Saint François, the orchestra is at least an equal partner, arguably even dominating. In the wake of these two grandest monuments came, respectively, the Méditations sur le mystère de la Sainte Trinité (1969) and Livre du Saint Sacrement (1984). They stand on their own as Messiaen's two largest organ cycles, but they can also be regarded as partner works to the oratorio and opera, exploring closely related theological territory for the more personal realm of the organ loft.

It should be emphasized that no suggestion is being made that Messiaen's contribution to the organ literature is anything other than substantial. It is rather that, by concentrating on his output for the concert hall, Messiaen paradoxically ensured that the works for his own

\footnotetext{
61 Samuel, Music and Color, p.118.

62 An indication of the change of circumstances is reflected in the statistics published each year in the Guide musical regarding concert life in Paris. In the 1924-25 season there were 45 orchestral concerts. This number rose steadily to reach 537 during the 1929-30 season, after which they went into an inexorable decline so that by the 1938-39 season there were just 321 orchestral concerts. For a vivid account of the malaise surrounding musical life in France in the post-war period, see Claude Samuel's booklet notes for the recent CD sets commemorating the Domaine Musical; Accord 4769209 and 4768862.
} 
instrument had greater impact. It is a mark of his achievement that his organ music not only kept abreast of current thinking, but also prompted such radical (and, mostly, secular) young composers as Boulez, Stockhausen, Xenakis, Barraqué and Goehr to attend organ recitals during the 1950s and 1960s.

La Nativité is rightly judged to mark a watershed in Messiaen's career. It is the point at which he added genuine rhythmic advances to his already-established harmonic approach. That said, La Nativité does not represent as much of a quantum leap in terms of technique as is sometimes claimed. The organ cycle contains virtually nothing harmonically that cannot be found in the early orchestral works. They also share much of the rhythmic approach, with additive rhythms being the crucial advance found in La Nativité. In many respects it is a matter of perspective, with La Nativité sounding more radical relative to other organ works of the time than the orchestral meditations do when put alongside Stravinsky, Schoenberg or Varèse.

The three orchestral meditations with which Messiaen began his career deserve greater consideration than hitherto has been the case, both as works in their own right, and for what they tell us about Messiaen's priorities as he began his career. They have suffered from the perceptions of Messiaen being an organist-composer and they have been overshadowed by L'Ascension, itself erroneously regarded for many years as a bona fide organ work. As we have seen, when writing Technique in 1942, Messiaen rated both Les Offrandes oubliées and the Hymne as more characteristic than L'Ascension. Le Tombeau and the Hymne have also been subjected to suppression, confusion, and mishaps. The absence of the Hymne from the catalogues of Messiaen's main French publishers has contributed to performances attaining a rarity value amongst the composer's works matched only by the limbo in which Le Tombeau languished for six decades. In addition, our perspective has been skewed by the successive radical innovations of orchestral writing made by Messiaen in works such as Turangalîla, Réveil des oiseaux and Chronochromie, overshadowing the more modest, but no less remarkable, contribution to the orchestral repertoire made by Messiaen before his twenty-fifth birthday. Les Offrandes oubliées, Le Tombeau resplendissant and the Hymne au Saint-Sacrement form a striking trinity of early orchestral meditations that create, if not an explicit triptych, then certainly a succession and progression of subjects, ideas and musical invention that is truly remarkable for such a young composer. From the plainchantinspired slow string melodies that frame Les Offrandes oubliés, via the dramatic free-falls and dizzying turbulence of Le Tombeau, to the bubbling sunny climax of the Hymne, Messiaen's grasp of the orchestra in these early years is already firm. He may have played the organ on Sundays, but he was no organist-composer. At the start of his career he was unequivocally a composer, and his medium was the orchestra.

I am extremely grateful to Nigel Simeone and Ronald Woodley for their insightful comments on a draft of this article. I should also like to thank Nigel for the loan of materials, and Barbara Haws and Richard Wandel at the NYPO archive, for providing me with copies of the programme and reviews for the 1947 performance of the Hymne. 


\section{APPENDIX}

\section{Les Offrandes oubliées}

Date of composition: 1930, Fuligny, Aube.

First performance: 19 February 1931, Paris, Théâtre des Champs-Élysées,

Orchestre Straram c. Walther Straram.

Scoring: 3 fl; 2 ob; 1 ca; 2 cl (A); 1 bcl (Bb); 3 bsn; 4 hn (F); 3 tpt (C); 3 tbn; 1 tba; timp (3 drums); bd; cym; tri; strings ('Quintette à cordes')

Publisher: Durand \& Cie, Paris

Date of publication: February 1931 (piano reduction by the composer).

November 1931 (orchestral score); parts - on hire

\section{Méditation symphonique}

i) La Croix (The Cross)

ii) Le Péché (Sin)

iii)L'Eucharistie (The Eucharist)

(Sans interruption)

\section{Preface:}

Les bras étendus, triste jusqu'à la mort, sur l'arbre de la Croix vous répandez votre sang.

Vous nous aimez, doux Jésus, nous l'avions oublié.

Poussés par la folie et le dard du serpent,

dans une course haletante, effrénée, sans relâche,

nous descendions dans le péché comme dans un tombeau.

Voici la table pure, la source de charité,

le banquet du pauvre, voici la Pitié adorable offrant le pain de la Vie et de l'Amour.

Vous nous aimez, doux Jésus, nous l'avions oublié.

\section{Notable recordings:}

1 Orchestre de l'Association de Concerts Gabriel Pierné, Roger Désormière; rec. Paris, November 1942. Association Française d'Action Artistique AA6; EMI France 094638527527.

2 Orchestre de Paris, Serge Baudo; rec. Salle Wagram, Paris, $6 \& 8$ March 1968. VSM CVB2121; EMI CZS 7626692.

3 Orchestre Philharmonique de l'O.R.T.F., Marius Constant; rec. studio 3, O.R.T.F., March 1971. Erato STU 70673; ECD 71588; 2292 45505-2/IV;4509-91707-2.

4 Sinfonieorchester Südwestfunk Baden-Baden, Hans Zender; rec. Rosbaud-Studio SWF Baden-Baden, 1990. Amati ami 9003 / 1

5 Orchestre de l'Opéra Bastille, Myung-Whun Chung; rec. Salle Gounod, Opéra Bastille, Paris, September 1994. Deutsche Grammophon 445 947-2 GH.

6 Bundesjugendorchester, Heinz Holliger; live rec. Kölner Philharmonie, 8 April 1997. Ars Musici AMP 5082-2 


\section{Le Tombeau resplendissant}

Date of composition: 1931, Fuligny, Aube.

First performance: 12 Feb $1933,{ }^{63}$ Paris, Salle Pleyel, Orchestre Symphonique de Paris c. Pierre Monteux.

Scoring: $3 \mathrm{fl} ; 2$ ob; 1 ca; 2 cl (Bb); 1 bcl(Bb); 3 bsn; 4 hn (F); 3 tpt (C); 3 tbn; 1 tba timp (3 drums); 4 perc - i) tri; ii) tambourine; iii) cym; iv) bd; vn I; vn II; va; vc; db Publisher: Durand \& Cie, Paris

Score-April 1997; Parts-on hire.

\section{Preface:}

Ma jeunesse est morte : c'est moi qui l'ai tuée. Colère qui s'élance, colère qui déborde! colère comme une fusée de sang, colère comme un coup de marteau! Un cercle à la gorge, la rage dans les mains, la froide haine sur le front! Désespoir et larmes!

Ma jeunesse vivait d'une musique de fleurs. Un escalier enchanté s'offrait à mes yeux. L'oiseau bleu des illusions l'éclairait de son plumage. Joyeusement mélancolique, la mélodie de l'atmosphère s'élevait.

Ma jeunesse est morte : c'est moi qui l'ai tuée. Fureur, où me conduis-tu? Arbres, pourquoi brillez-vous dans la nuit ? Avancez, reculez, tendez vos bras! Des vagues à mes oreilles! cela craque, tourne, danse, clame, hurle : le vide entre en moi !

Quel est ce tombeau resplendissant? C'est le tombeau de ma jeunesse, c'est mon cour. La flamme sans cesse jaillissante, l'aveuglante clarté d'une voix intérieure l'illuminent : "Venez à moi, vous tous qui êtes épuisés de travail et qui êtes chargés, et je vous soulagerai. Bienheureux ceux qui sont doux, car ils posséderont la terre. Bienheureux ceux qui pleurent, car ils seront consolés. Bienheureux ceux qui ont le cour pur, car ils verront Dieu.»

\section{Notable recordings:}

1 Young Musicians' Symphony Orchestra, James Blair; live rec. February 1984 - N.B. Earliest known broadcast performance. British Library National Sound Archive NP8178BW.

2 Orchestre de l'Opéra Bastille, Myung-Whun Chung; rec. Salle Gounod, Opéra Bastille, Paris, September 1994. Deutsche Grammophon 445 947-2 GH.

\section{Hymne au Saint-Sacrement}

Date of composition: 1932, Paris. Reconstructed 1947. ${ }^{64}$

First performance: (original version) 23 March 1933, Théâtre des Champs-

Élysées, Orchestre Straram, c. Walther Straram.

13 March 1947, New York, NYPO, cond. Leopold Stokowski (reconstruction) ${ }^{65}$

Scoring: $3 \mathrm{fl} ; 2$ ob; 1 ca; 2 cl (Bb); 1 bcl (Bb); 3 bsn; 4 hn (F); 3 tpt (C); 3 tbn; 1 tba; timp (3 drums); tri; susp. cym; bd; vn I; vn II; va; vc; db

Publisher: Original - Durand \& Cie, Paris (for hire only); lost c. 1942.

Reconstructed version - Broude Brothers, New York; Score 1974; Parts - on hire.

${ }^{63}$ The Durand score published in 1997 erroneously gives the date of the first performance as 12 March 1933

${ }^{64}$ Messiaen may have begun working on the reconstruction in 1946. The first mention of the work in the New York Philharmonic Archives is in an internal listing, dated 13 February 1947, of Stokowski's programmes in March of that year. It is clear from earlier material in the archive that these concerts were added at a late stage. A note in brackets proclaims ' $1 \mathrm{st}$ performance anywhere' for Messiaen's Hymne, as distinct from Stokowski's arrangement of Debussy's Soirée dans Grenade, which states '1st time by the Society' (New York Philharmonic Archives, 001-11-027).

${ }^{65}$ The concert was repeated the following afternoon, Friday 14 March, and again on Sunday 16 March, when it concluded the concert, this accolade being accorded as the Hymne was the only work not to be broadcast (New York Philharmonic Archives, 001-11-027). 


\section{Preface:}

Je chante le don de la divine essence,

La chair de Jésus-Christ

Sa chair et son sang,

Je chante le banquet du combat et de la force

(Lien d'unité dans l'amour)

Je chante qui est en nous (et nous sommes en lui)

Le pain vivant descendu du ciel,

Le pain vivant qui donne la vie,

La vie éternelle!

\section{Notable recordings:}

1 Radio-Sinfonieorchester Frankfurt, Leopold Stokowski; live rec., 31 May 1955. Music \& Arts CD-4770 ${ }^{66}$

2 Orchestre Philharmonique de l'O.R.T.F., Marius Constant; rec. studio 3, O.R.T.F., March 1971. Erato STU 70763; ECD 71588; 229245505-2/IV; 4509-91707-2.

3 Rundfunk-Sinfonieorchester Saarbrücken, Hans Zender; live rec. Kaiserslautern, Fruchthalle, 21 April 1978. CPO compact disc 999 481-2.

\section{L'Ascension}

Date of composition: Begun May 1932 in Paris; finished July 1932 in Neussargues; orchestrated May-July 1933 in Monaco.

First performance: 9 Feb 1935, Paris, Concerts Siohan, c. Robert Siohan.

Scoring: $3 \mathrm{fl} ; 2 \mathrm{ob} ; 1 \mathrm{ca} ; 2 \mathrm{cl}$ (A and Bb); 1 bcl (Bb); 3 bsn; $4 \mathrm{hn}$ (F); 3 tpt; 3 tbn; 1 tba; timp (3 drums); tri; cym; tambourine; bd; strings (16.16.14.12.10)

Publisher: Alphonse Leduc, Paris.

Score-June 1948; Parts-on hire.

Quatre Méditations symphoniques pour orchestre

i Majesté du Christ demandant sa gloire à son Père

Père, l'heure est venue, glorifie ton Fils, afin que ton Fils te glorife.

(Prière sacerdotale du Christ, évangile selon Saint Jean).

ii Alléluias sereins d'une âme qui désire le ciel

Nous vous en supplions, ô Dieu, ... faites que nous habi-

tions aux cieux en esprit.

(Messe de l'Ascension).

iii Alléluia sur la trompette, Alléluia sur la cymbale Le Seigneur est monté au son de la trompette...

Nations, frappez toutes des mains; célébrez Dieu par des cris d'allégresse!

(Psaume 46).

iv Prière du Christ montant vers son Père

Père,...j'ai manifesté ton nom aux hommes...

Voilà que je ne suis plus dans le monde; maix eux sont dans le monde, et moi je vais à toi.

(Prière sacerdotale du Christ, évangile selon Saint Jean).

\footnotetext{
${ }^{66}$ The back cover describes this as the 'European première' without specifying that this is of the reconstruction.
} 


\section{Notable recordings:}

1 New York Philharmonic Orchestra, Leopold Stokowski; rec. 30th Street Studios, New York, 21 February \& 21 March 1949. Matrix: XCO-39365 / 67; XCO-41021/22; Columbia MM 893; Columbia ML 4214; Columbia WL 5140; (date: 21/ 02,21/03/49) Cala CACD 0533.

2 London Symphony Orchestra, Leopold Stokowski; live rec. Royal Festival Hall, 18 June 1970 (?20 June 1970). Intaglio INCD 7421; Music \& Arts CD-4787.

3 London Symphony Orchestra, Leopold Stokowski; rec. Kingsway Hall, London, 22 \& 23 June 1970. London SPC 21060; Decca PFS 4203; King GT 9165; London POCL 90013; Cala CACD 0525.

4 Orchestre Philharmonique de l'O.R.T.F., Marius Constant; rec. studio 3, O.R.T.F., 1971. Erato STU 70673; ECD 71587; 2292-455052/III; 4509-91706-2.

5 Orchestre de l'Opéra Bastille, Myung-Whun Chung; rec. Opéra de Paris-Bastille, Salle R 1, October 1991. Deutsche Gramophon 435 854-2 GH.

6 Chicago Symphony Orchestra, Pierre Boulez; live rec. Orchestra Hall, Chicago, 29 \& 30 November 1996. Chicago Symphony Orchestra From the Archives Vol.19 CSO-CD05-1

7 National Polish Radio Symphony Orchestra, Antoni Wit; rec. Grzegorz Fitelberg Concert Hall, Katowice, 5-8 October 1998. Naxos 8.554478-79.

8 SWR Sinfonieorchester Baden-Baden und Freiburg, Sylvain Cambreling; rec. Konzerthaus Freiberg, SWR, 13-15 September 1999. Hännsler Classic CD 93.005. 